\title{
Relay Translation of Traditional Javanese Advices From Butir-ButirBudaya Jawa's Book
}

\author{
Sujatmiko ${ }^{1}$, M.R. Nababan ${ }^{2}$, Djatmika ${ }^{3}$, Supana $^{4}$ \\ \{sujatmikomiko2018@student.uns.ac.idㄹ. amantaradja@yahoo.com².,djatmika@staff.uns.ac.id., \\ supana_77@staff.uns.ac.id.
}

Postgraduate Student of Universitas Sebelas Maret, Surakarta, Indonesia ${ }^{1}$, Faculty of Teacher Training and Education Universitas PGRI Yogyakarta, Yogyakarta, Indonesia ${ }^{1}$, Faculty of Cultural Science Universitas Sebelas Maret, Surakarta, Indonesia ${ }^{2}$, Faculty of Cultural Science Universitas Sebelas Maret, Surakarta, Indonesia ${ }^{3}$, Faculty of Cultural Science Universitas Sebelas Maret, Surakarta, Indonesia ${ }^{4}$

\begin{abstract}
This research focused on relay translation of traditional Javanese advices from BBBJ's book and it aimed to explore the translation techniques and the impact to the translation quality. The data were analysed using Molina and Albir and Nababan et al. Content analysis and FGD were used to collect the data. Data validity techniques used data source and method triangulation. Data analysis technique used Spradley's model such as domain, taxonomy and componential analysis. The findings revealed that the translation technique applied were establish equivalent $(75,02 \%)$, modulation $(6,47 \%)$, explicitation $(5,88 \%)$, paraphrase $(4,79 \%)$, implicitation $(3,50 \%)$ and transposition $(1,18 \%)$. The average of translation quality from Javanese to Indonesia was 2,95and from Indonesia to English was 2,96.
\end{abstract}

Keywords: Relay Translation, Translation Technique, Translation Quality, Butir-Butir Budaya Jawa’s Book.

\section{Introduction}

Javanese people are quantitatively large and the cultural values that they profess to realize or not contribute to and a major influence on the behavior of the life of the nation, state and society. Although the values of "kejawen" are more often associated with the $2^{\text {nd }}$ President of Indonesia, collectively the leaders before and after more or less have the same cultural background.

There is no value system that can claim purely without influence or intersect with other value systems. Likewise, the value system that is rooted in Javanese culture and reality has been combined with various other value systems that live in the archipelago. In other words, the granules of traditional Javanese advices have a very broad influence on social life and the formation of cultural values that people adhere to. Pak Harto ruled for approximately 32 years, and that meant that all thoughts, words and actions or decisions taken were also inseparable from the values that he held. The points that traditional Javanese advices are excerpts of Javanese cultural teachings that have a deep and complex theological and philosophical content. Religious values are the philosophy which is the most fundamental foundation of the life of the Indonesian people in the 
nation and society. Spirituality that lives in the middle of Javanese society is a unifying element that maintains the balance of life maintained for hundreds of years.

A teaching that is rooted strongly in local wisdom has a high degree of relevance to the context of social and religious life of the community from time to time, to the future. Thus, the scientific study of this paper is expected to make a positive contribution to society in general, and specifically for Javanese culture which is an inseparable part of the Indonesian cultural mosaic.

Javanase people uses Java language in their daily life to deliver the ideas. One of the local wisdom which is spoken by Javanese people is traditional advices. Traditional advices have the meaning of life and still relevant until up to present time. Javanese people uses traditional advicesdue to they have deep meaning. The examples of traditional Javanese advices such as "mikul dhuwur mendhem jero", "ngunduh wohing pakarti", "becik ketitik ala ketara”, etc.

Those traditional Javanese advices can not be separated from Javanese's daily life, even they regarded them as "daily saying" which have no meaning. It can be happened due to they can be identified easily [35]. The second President of Indonesia, Soeharto has created a book namely "Butir-Butir Budaya Jawa" (BBBJ) as one effort to keep the traditional Javanese advices. It published in 1987 [27]. BBBJ serves in two dimensions; Pituduh (guidances) and wewaler (prohibitions). BBBJ has relay translation inside which is Javanese text as the source text (ST) translated into English as target text (TT) via Indonesia language as mediated text (MT). The examples of relay translation in BBBJ's book :

(1) Pangeran iku ora sare (ST) $\longrightarrow$ Tuhan itu tidak tidur (Tuhan mengetahui segalagalanya) (MT) $\longrightarrow$ The Lord doesn't sleep (The Lord is aware everything) (TT).

(2) Mikul dhuwur mendhem jero $(\mathrm{ST}) \longrightarrow$ Memikul tinggi menanam dalam (MT) $\longrightarrow$ Carry high burry deep (the body of your deceased parents. Keep their eventual infamous deeds with yourself, talk only of their good deeds) (TT).

The questions may appear. What are the translation techniques applied in those examples? and what are the impact of translation tehniqeus to the translaton quality? Two questions as research problems and would be revealed in this paper.

The translation experts have their own terminology to mention the relay translation. The experts who called it as indirect translation (ITr) [12], [6], [7], [15], [39], [21], [30], [29], and [22]. Meanwhile, [38] call it as second hand translation. This following experts deals to call it as relay translation [2], [3], [32], [26], [1], and [33]. "mediated translation" [24], "double translation" [5], and "retranslation" [13].

Why a relay translation happen? First, both lack of knowledge and lack of translator who has a good competencies to do direct translation [26], [40], and [22]. Second, lack of access to the source language [25]. Third, there is a far distance of source text and target text (language 1 to language 3) [31].

From those reasons, a relay translation happens which involves three different languages [12], [29], [15], [32], [26], [4], [22], and [33]. Those three different languages has their own position namely source text (ST), mediated text (MT), and target text (TT). The example of relay translation for example from Chinese (TT) to English (TT) via France (MT).

Many reseachers have conducted the relay translation researchs [42], [8], [3], and [9]. English literatures can be enjoyed by Russian via France and Germany (MT) [42]. . In the nineteenth, France language is very popular to be used as mediated text (MT). Another example of relay translation, from Calderon language to Russian via Germany in 
1820 [42]. Armenian Vakhtang Ananian language is translated to Czech, Polis and English via Russian language [43]. Their research result did not discuss the translation technique and translation quality. The previous studies which uses BBBJ's book as their data source [37], [19], [23], and [20]. Their studies did not focus on translation aspect.

Therefore, the researchers found the research gap. A relay translation from Javanese to English via Indonesia language from BBBJ's book which focus on translation technique and translation quality has not be conducted by other researchers and fulfill the originality aspect.

\section{Literature Review}

\subsection{Relay Translation}

The translation experts have their own terminology to mention the relay translation. The experts who called it as indirect translation (ITr) [12], [6], [7], [15], [39], [21], [30], [29], and [22]. Meanwhile, [38] call it as second hand translation. This following experts deals to call it as relay translation [2], [3], [32], [26], [1], and [33]. "mediated translation" [24], "double translation" [5], and "retranslation" [13].

The researchers used relay translation terminolog according to [2] states that "relay can be defined as a mediation from source to target language in which the translational product has been realised in another language than that of the original; the defining feature is that the intermediary translation has an audience that is consumers, of its own".

[32] states that "relay translation is the translation of translated text (either spoken or written) into a third language". Other expert is [26] states that "relay translation refers to a chain of (at least) three texts, ending with a translation made from other translation; original (ST) to intermediate text (IT) then to target text (TT)". [32], [33], has opinion that "relay translation is the translation of translated text (either spoken or written) into a third language". Meanwhile, [1] states that "any translation mediated by another translation".From those definitions, we may concluded that a relay translation is a translation of a translation; a double translation which is involved three languages differs.

\subsection{Translation Technique}

The researchers used translation technique proposed by [17] which simplified the unclear terminologies proposed by other experts. Molina \& Albir offers translation techniques as followings:

- Amplification. To introduce details that are not formulated in the ST: information,explicative paraphrasing, e.g., when translating from Arabic (to Spanish ) to add the Muslim month of fasting to the noun Ramadan.

- Borrowing. To take a word or expression straight from another language. It can be pure (without any change), e.g., to use the English word lobby in a Spanish text, or it can be naturalized (to fit the spelling rules in the TL), e.g., gol, fútbol, líder, mitin.

- Calque. Literal translation of a foreign word or phrase; it can be lexical or structural, e.g., the English translation Normal School for the French École normale.

- Compensation. To introduce a ST element of information or stylistic effect in another place in the TT because it cannot be reflected in the same place as in the ST. 
- Description. To replace a term or expression with a description of its form or/and function, e.g., to translate the Italian panettone as traditional Italian cake eaten on New Year's Eve.

- Discursive creation. To establish a temporary equivalence that is totally unpredictable out of context, e.g., the Spanish translation of the film Rumble fish as La ley de la calle.

- Established equivalent. To use a term or expression recognized (by dictionaries or language in use) as an equivalent in the TL, e.g., to translate the English expression They are as like as two peas as Se parecen como dos gotas de agua in Spanish.

- Generalization. To use a more general or neutral term, e.g., to translate the French guichet, fenêtre or devanture, as window in English.

- Linguistic amplification. To add linguistic elements. This is often used in consecutive interpreting and dubbing, e.g., to translate the English expression No way into Spanish as De ninguna de las maneras.

- Linguistic compression. To synthesize linguistic elements in the TT. This is often used in simultaneous interpreting and in sub-titling, e.g., to translate the English question Yes, so what? With ¿Y?, in Spanish.

- Literal translation. To translate a word or an expression word for word, e.g., They are as like as two peas as Se parecen como dos guisante, or, She is reading as Ella está leyendo.

- Modulation. To change the point of view, focus or cognitive category in relation to the ST; it can be lexical or structural, e.g., to translate as you are going to have a child, instead of, you are going to be a father.

- Particularization. To use a more precise or concrete term, e.g., to translate window in English as guichet in French.

- Reduction. To suppress a ST information item in the TT, e.g., the month of fasting in opposition to Ramadan when translating into Arabic.

- Substitution (linguistic, paralinguistic). To change linguistic elements for paralinguistic elements (intonation, gestures) or vice versa, e.g., to translate the Arab gesture of putting your hand on your heart as Thank you.

- Transposition. To change a grammatical category, e.g., He will soon be back translated into Spanish as No tardará en venir, changing the adverb soon for the verb tardar, instead of keeping the adverb and writing: Estará de vuelta pronto.

- Variation. To change linguistic or paralinguistic elements (intonation, gestures) that affect aspects of linguistic variation: changes of textual tone, style, social dialect, geographical dialect, etc., e.g., to introduce or change dialectal indicators for characters when translating for the theater, changes in tone when adapting novels for children, etc.

\subsection{Translation Quality}

Translation quality assesment by [18] as follows : (1) Accuracy, translator should deliver the message from source text to target text properly and accurately. Accuracy is the most important thing in translation quality due to finding the equivalence meaning is very crucial one. (2) Acceptability, a translation should be natural to make it acceptable in target language system, it refers to the naturalness of the translated text. (3) Readibility, it considers the readers' understanding toward the the text. The measurement is needed to know how understandable the translation for the readers. 
The translation can be said to be good if the readers understand well the meaning, idea, and context of the text of source language.

\section{Method}

This research is qualitative belongs to embedded research due to the research focus have determined by the researchers. Data were traditional Javanese advices from Pituduh (guidance) dimension. Data sources from document and raters. Document was BBBJ's book and raters who involved directly in FGD.

Content analysis and FGD were chosen to collect the data. Content analysis is used to analyse the linguistic data and FGD to collect the translation data. The researcher also involved in FGD. FGD was conducted to identify the translation technique applied in the relay translation and assess the translation quality. The FGD used to obtain the objectivity of quality translation assesment. Data were analysed using two frameworks; translation technique by [17] and translation quality assesment by [18].

Accuracy, acceptability and readibility were used to assess the translation quality. A good translation must fulfill those aspects. Data validity used data source and method triangulation. Data source triangulation was BBBJ's book as main document and supporting data from previous related research. Method triangulation from content analysis and FGD. Data analysis technique used Spradley's model such as domain, taxonomy and componential analysis.

\section{Findings}

FGD results showed the translation techniques applied were: establish equivalent $(75,02 \%)$, modulation $(6,47 \%)$, explicitation $(5,88 \%)$, paraphrase $(4,79 \%)$, implicitation $(3,50 \%)$, and transposition $(1,18 \%)$. The following explanation describes the use of each translation technique applied. This explanation only focuses on techniques that exceeded more than one percent because it is significant to be discussed.

Table 1 : The Distribution of Translation Techniques Both from ST to MT and MT to TT

\begin{tabular}{llc}
\hline Translation techniques & Frequency & $\%$ \\
\hline Establish Equivalent & 3942 & 75,02 \\
\hline Modulation & 340 & 6,47 \\
\hline Explicitation & 309 & 5,88 \\
\hline Paraphrase & 252 & 4,79 \\
\hline Implicitation & 184 & 3,50 \\
\hline Transposition & 62 & 1,18 \\
\hline
\end{tabular}


Data display followed [12] as described :

Table 2 : Kittel \& Frank's Model

\begin{tabular}{|c|cc|}
\hline Source Text $\longrightarrow \begin{array}{l}\text { Mediating Text } \\
\text { /Target Text 1 } \\
\text { /Source Text 2 }\end{array}$ & $\longrightarrow$ Target Text 2 \\
$($ ST 1) & $($ MT, TT 1, ST 2) & (TT 2) \\
\hline
\end{tabular}

\section{Establish Equivalent}

This technique use a term or expression recognized (by dictionaries or language in use) as an equivalent in the target language [17].

Example :

(1) Pangeran iku ora sare $(\mathrm{ST}) \rightarrow$ Tuhan $\underline{\text { itu tidak tidur }}$ (MT)

$\longrightarrow$ The Lord doesn't sleep (TT).

(2) $\underline{\text { Sing prasaja }}(\mathrm{ST}) \longrightarrow$ Bersahajalah $(\mathrm{MT}) \longrightarrow$ Be simple $(\mathrm{TT})$

The word iku, ora and sare in ST (example 1) were translated into itu, tidak and tidur in MT and translated into doesn't sleep in TT. Those translation were translated according to dictionary. Pangeran was translated into Tuhan and The Lord is not using establish equivalent technique.The word itu in TT is embeded in doesn't. The example (2) also translated using establish equivalent.

\section{Modulation}

This technique is change the point of view, focus or cognitive category in relation to the ST; it can be lexical or structural [17].

Example :

(1) Pangeran iku ora mbedak-mbedakake kawulane $(\mathrm{ST}) \longrightarrow \underline{\text { Tuhan }}$ itu tidak membeda-bedakan makhluk-Nya (MT) $\longrightarrow$ The Lord does not discriminate his servants (TT).

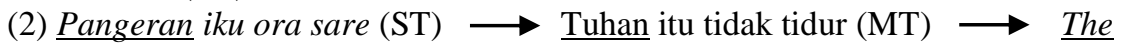
Lord doesn't sleep (TT).

In the example (1) and (2), the word Pangeran (ST) was translated into Tuhan (MT) and The Lord (TT). The translator of MT and TT have changed the point of view toward the concept of Pangeran. Javanese people like to mention Pangeran and Gusti. Pangeran, Tuhan and The Lord refers to The Almighty God.

\section{Explicitation}

This technique is to introduce details that are not formulated in the source text [17].

Example :

(1) Ala ketara becik ketitik (ST) $\longrightarrow$ Yang buruk dan yang baik akhirnya akan tampak $(\mathrm{MT}) \longrightarrow$ Evil will eventually be revealed, good will eventually be recognized (TT).

(2) Jer basuki mawa beya $(\mathrm{ST}) \rightarrow$ Kalau ingin selamat (berhasil) harus ada biayanya (pengurbanan) $(\mathrm{MT}) \rightarrow$ Success requires cost $(\mathrm{TT})$. 
The explicitation technique can be seen in the example (1) and (2) especiallly in MT. In TT, translator used paraphrase technique. Translation in MT both example (1) and (2) introduce details which is not formulated in the source text.

\section{Paraphrase}

This technique is to introduce details that are not formulated in the source text [17].

Example :

(1) Ala ketara becik ketitik (ST) $\longrightarrow$ Yang buruk dan yang baik akhirnya akan tampak (MT) $\rightarrow$ Evil will eventually be revealed, good will eventually be recognized (TT).

(2) Jer basuki mawa beya (ST) $\longrightarrow$ Kalau ingin selamat (berhasil) harus ada biayanya (pengurbanan) (MT)_ $\longrightarrow$ Success requires cost $(\mathrm{TT})$

The translator used paraphrase technique in translating the ST. Paraphrase technique can be seen in the TT. Translator introduced details concept of ST in the target text.

\section{Implicitation}

This technique is to allow the situation to indicate information that is explicit in the ST [17].

Example :

(1) Ala lan becik iku dumunung ana awake dhewe (ST) $\rightarrow$ Baik dan buruk ada pada dirinya sendiri (MT) $\longrightarrow$ Good and evil is within you (TT).

(2) Bandha iku anane aneng donya, mula yen mati ora digawa (ST)

Harta benda itu adanya di dunia (MT) $\longrightarrow$ Wealth exists in this world, you do not take it with you on your death (TT).

The word ada (1) in MT was the example of implication tehcnique applied by translator and also you do not take it with you on your death (2) in TT also implication technique applied by translator. The word ada was indicated the information in ST. Mula yen mati ora digawa (ST) was translated into you do not take it with you on your death (TT). The translator emphasized this sentence that we don't need to take our wealth if we death.

\section{Transposition}

This techniqueis to change a grammatical category [17]

Example :

(1) Melik nggendhong lali $(\mathrm{ST}) \longrightarrow$ Ingin sekali, menyebabkan lupa (MT)

$\longrightarrow$ Desire causes forgetfulness (TT).

(2) Sing sapa mikani anane Pangeran, kalebu urip kang sempurna $(S T) \longrightarrow$

Barangsiapa mengerti adanya Tuhan, tergolong sempurna hidupnya (MT)

Whoever recognize the Lord's existence, lives perfectly (TT).

Translator changed the grammatical category in the example (1). The word lali in ST is verb then in TT became forgetfulness (noun). Meanwhile in the example (2), the transposition technique can be seen in TT. Sempurna hidupnya in MT was translated into lives perfectly. There was a grammatical change from adjective became adverb. The changing of the grammatical category doesn't change the meaning. 


\section{The Impact of Translation Technique to the Translation Quality}

The translation techniques applied have impact to the translation quality. Translation technique influenced the accuracy, acceptability and readiblity. The implementation of reduction and discursive creation for example affected the accuracy of the message. Therefore, the score of accuracy from Javanese to Indonesia was 2,94, acceptability 2,94 and readibility 2,96. Meanwhile, the score of accuracy from Indonesia to English was 2,93, acceptability 3 and readibility 3. The average score of translation quality from Javanese to Indonesia was 2,95 and the average score of translation quality from Indonesia to English was 2,96. Therefore, it can be concluded that the accuracy score of Javanese to Indonesia was better than from Indonesia to English, on the other hand, the acceptability and readibility of message from Indonesia to English was perfect. (score 3). Overall, the translation quality from Indonesia to English translation was better than from Javanese to Indonesia translation.

\section{Discussion}

From the findings, the establish equivalent translation technique was very dominant applied by translator both from Javanese to Indonesia and Indonesia to English. The next dominant techniques applied were modulation, explicitation, paraphrase, implicitation and transposition. Those translation techniques were applied by translation to reach the good translation which fulfill the accuracy, acceptability and readibility. Other translation techniques applied also influenced the accuracy, acceptability and readibility which determined the score of translation quality.

The researcher also found the fact that explicitation and paraphrase translation technique were separated, they have their own role and effect to the translation quality. It means that this findings, is a novelty. If we see the translation technique by [17], those translation techniques (explicitation and paraphrase) became one technique namely amplification technique.

Other novelty from the findings that it was not a line with the statement from [29] that a relay translation has a negative stigma "apoor copy of a poor copy from the original". The proof was the result of translation quality score from Indonesia to English version was 2,96 . It means almost perfect, almost reach a good translation.

\section{Conclusion}

It can be concluded that the dominant translation techniques applied were establish equivalent $(75,02 \%)$, modulation $(6,47 \%)$, explicitation $(5,88 \%)$, paraphrase $(4,79 \%)$, implicitation $(3,50 \%)$, and transposition $(1,18 \%)$. The average score of translation quality from Javanese to Indonesia was 2,95 and the average score of translation quality from Indonesia to English was 2,96. Therefore the translation quality from Indonesia to English translation was better than from Javanese to Indonesia translation. 


\section{References}

[1] Assis Rosa, A., Pięta, H. and Maia, R. B.Theoretical, Methodological and Terminological Issues regarding Indirect Translation: An Overview. Translation Studies, 10 (2). 2017b: 113-132.

[2] Dollerup, C.Relay and Support Translations. In: A. Chesterman, N. Gallardo and Y. Gambier (eds.). Translation in Context: Selected Contributions from the EST Congress. Amsterdam: John Benjamins; 2000: 17-26.

[3] Dollerup, C. Relay in Translation. 2008. Universitatea din Bucuresti: Provided by Diacronia.ro

[4] Dollerup, C. "Relay in Translation." In Cross-linguistic Interaction: Translation, Contrastive and Cognitive Studies, edited by Diana Yankova, original edition. Sofia: St. Kliminent Ohridski University Press. 2014: 21-32

[5] Edström, Bert."The Transmitter Language Problem in Translations from Japanese into Swedish.". 1991. Babel 37 (1) : 1-13.

[6] Gambier, Yves. La retraduction, retour et detour, META. 1994; 39 (3) : 413-417.

[7] Gambier, Yves. Working with relay: An old story and a new challenge. In speaking in tongues: Language across contexts and uers, Luis Perez Gonzales (ed). University of Valencia Press. 2003: 47-66.

[8] Gorlee, D. Bending back and breaking (a review of Mary Ann Caws surprised in Translation). Symploke 15. 2007: 341-352.

[9] Hadley, James. "Indirect Translation and Discursive Identity: Proposing the Concatenation Effect Hypothesis." Translation Studies 10 (2). 2017: 183-197.

[10] Haq, Muhammad Zaairul. Mutiara Hidup Manusia Jawa. cet.2. Yogyakarta: Aditya Media Publishing. 2013.

[11] Kadiu, Sylvia. "David Bellos' Indirect Translation of Ismail Kadare's 'The File on H': A Contextual Analysis."International Journal of Literary Linguistics. 2016.

[12] Kittel, Harald \& Frank, Armin Paul (eds). Interculturality and Historical Study of Literary Translations. Berlin: Erich Schmidt Verlag. 1991.

[13] Koskinen, Kaisa, \& Outi Paloposki. Retranslation. In Handbook of Translation Studies, edited by Yves Gambier adn Luc Van Doorslaer. Amsterdam: John Benjamins. 2010: 294-298.

[14] Larson, M.L. Meaning Based Translation (2nd edition). New York : University Press of America. 1997.

[15] Lee, Hyung-jin. Survival Through Indirect Translation. Journal of Language \& Translation 9-2008: 71-93.

[16] Li, Wenjie. The Complexity of Indirect Translation; Reflections on the Chinese Translation and Reception of H. C. Andersen's Tales. Orbis Litterarum: Published by John Wiley \& Sons Ltd. 2017: 181-208.

[17] Molina \& Albir. Translation Technique Revisited; A Dynamic and Functionalist Approach. META Journal XLVII. 2002; 4: 498-512.

[18] Nababan, M., \& Nuraeni, A. Pengembangan Model Penilaian Kualitas Terjemahan. Kajian Linguistik dan Sastra. 2012; 24 (1) : 39-57.

[19] Novebrianti, Prabakti Siwi. Nilai Kemanusiaan dalam Butir-Butir Budaya Jawa. Skripsi. Depok : Universitas Indonesia. 2008

[20] Nurhayati, Alvi. Nilai Karakter Jawa pada Ungkapan Tradisional Jawa dalam Buku Butir-Butir Budaya Jawa. Skripsi. Universitas Negeri Malang: Jurusan Sastra Indonesia, Fakultas Sastra. 2017. 
[21] Pieta, Hanna. Patterns in (in)directness : An exploratory case study in the external history of Portuguese translations Polish literature (1855-2010). Target. 24 (2). 2012: 310-337.

[22] Pieta, Hanna. Indirect Translation: Main Trends in Practice and Research. 2019: 21-23.

[23] Purwanto, Wachid Eko. Konsep Kepemimpinan Soeharto dalam Butir-Butir Budaya Jawa. Jurnal Bahastra, 37(1), Maret. 2017: 73 -88.

[24] Pym, Anthony. Translation Research Terms: A tentative glossary for moments of perplexity and dispute. In translation research Projects 3, Anthony Pym (ed). Tarragona: Intercultural Studies Group. 2011: 75-110.

[25] Ringmar, Martin. 'Roundabout routes.' Some remarks on indirect translations. In: Francis Mus, ed. Selected papers of the CETRA research seminar in Translation Studies. 2006.

[26] Ringmar, Martin. Relay Translation. Retranslation. In Handbook of Translation Studies, edited by Yves Gambier adn Luc Van Doorslaer. Amsterdam: John Benjamins. 2012: 141-144.

[27] Rukmana, Siti Hardiyanti. Butir-Butir Budaya Jawa. Jakarta: Yayasan Purna Bhakti Pertiwi. 1987.

[28] Santosa, Riyadi. Metode Penelitian Kualitatif Kebahasaan. Surakarta: UNS Press. 2017.

[29] Shuttleworth, M \& Cowie, M. Dictionary of Translation Studies. NewYork: Routledge. 2014.

[30] Špirk, J. Censorship, Indirect Translation and Non-Translation: The (Fateful) Adventures of Czech Literature in 20th-Century Portugal. Newcastle upon Tyne: Cambridge Scholars. 2014.

[31] St. Andre, James. Retranslation as argument: canon formation, professionalization, and rivalry in 19th century sinological translation. Cadernos de Traduçao. 11(1). 2003b: 5993.

[32] St. André, James. "Relay." In Routledge Encyclopedia of Translation Studies, 2nd ed., edited by Mona Baker and Gabriela Saldanha. London: Routledge. 2009: 230-232.

[33] St. Andre, James. Relay. Routledge Encyclopedia of Translation Studies, 3rd ed., edited by Mona Baker \& Gabriela Saldanha. London and New York: Routledge. 2020: 470473.

[34] S. Stymne \& C. Smith. On the Interplay Between Readability, Summarization, and Mtranslatability. In proceedings of the Fourth Swedish Language Technology Conference (SLTC), Lund, Sweden. 2012: 70-71.

[35] Sumodiningrat, Gunawan \& Wulandari, Ari. Pitutur Luhur Budaya Jawa. Yogyakarta: NARASI (Anggota IKAPI). 2014.

[36] Sutopo, H.B. Metodologi Penelitian Kualitatif ; Dasar Teori dan Terapannya dalam Penelitian Edisi Kedua.Surakarta: UNS Press. 2006.

[37] Sutrisno, Slamet. Unsur-Unsur Kefilsafatan dalam Buku Butir-Butir Budaya Jawa. Jurnal Filsafat, 29, Juni. 1999: 19-28.

[38] Toury, Gideon. Descriptive Translation Studies and Beyond. Amsterdam: Benjamins. 1995.

[39] Toury, Gideon. "A Lesson from Indirect Translation." In Descriptive Translation Studies and Beyond. Rev. ed. Amsterdam: John Benjamins. 2012: 161-178.

[40] Wasbourne, K. Nonlinear Narratives: Paths of Indirect and Relay Translation. META LVIII (3). $2013: 607-625$. 
[41] Yu, Zhongli. Relay Translation of Feminism in China: An Intralingual Case. Journal of Translation Studies 1(2), New Series). 2017: 47-73.

[42] Zaborov, P. "The mediating literature" in the history of Russian-Western literary relations. In: M. P. Alekseev (ed.). Mezhdunarodnye sviazi russkoi literatury [International relations of Russian literature]. Moscow: Izdatel'stvo Akademii Nauk. 1963: 64-85.

[43] Zaborov, P. Die Zwischenubersetzung in der Geschichte der russischen Literatur. In Ubersetzung. Translation. Traduction (HSK 26:3), Harald Kittel et al (eds). Berlin/Boston: Walter de Gruyter. 2011: 2066-2073. 